\title{
Examining Europe's energy equation
}

$\mathrm{T}^{\mathrm{H}}$ HE SO-CALLED energy crisis of 1973 and 1974 may, in retrospect, be viewed as a blessing in disguise for, if nothing else, it applied the minds of nations to something they had chosen to ignore for decades: the sensible planning of energy resources for the future. Cheap and plentiful crude oil, mainly from the Middle East, had followed supplies of cheap coal as the basic energy provider and it seemed that everyone had been lulled into a false sense of security. As Mr Frank Zarb, the US Federal Energy Administrator, pointed out in London recently, the industrialised world had paid dearly for its mistake.

The first world conference on energy and raw materials, held in Paris in December last year; the establishment of the International Energy Agency (IEA) by the OECD; the bid for a common energy policy within the EEC -all these are signs of a change in attitude to energy. The fact that the Paris conference produced very little in the way of solutions to the international problem is hardly surprising; the issues are both complex and fundamental. Similarly, it is understandáble that the IEA and the EEC are making heavy weather of finding common energy policies; after all, member states are only just beginning to get to grips with their individual plans.

But progress is being made. The EEC Nine, for instance, have already agreed on restrictions on the use of oil and gas in power stations and on the maintenance of minimum stocks of fuel in case of another energy emergency. They are now firmly committed to an energy conservation policy and to a programme to replace imported oil with alternative fucls. It is anticipated, for instance, that even if the EEC economy grows at $4 \%$ a year over the next decade, conservation measures should keep the growth of energy requirements down to no more than $3 \%$ : a saving of perhaps 250 million tonnes of oil equivalent in 1985. (Last year energy consumption in western Europe was down some $15 \%$ on earlier forecasts although it is difficult to measure just how much of this was due to deliberate conservation rather than the general economic recession.)

New agreements also emerged from the stormy EEC summit meeting in Rome early in December last year and

\section{Sorry, for copyright reasons some images on this page may not be available online}

Oil: 'Already there is a feeling in the industry that the plums of the North Sea have been picked"

these could well prove to be the cornerstones of future European energy policies. For a start there now seems to be widespread acceptance, both in Europe and in the wider IEA, that there should be a minimum safeguard price for oil-in essence a safety net for producers like the UK and Norway should world prices tumble.

Second, Mr Harold Wilson's apparently ignominious stand-down from his demand for a separate seat at the Paris energy talks did persuade France to back an oil-sharing policy in times of crisis: surely a vital principle in any unified energy policy.

Now comes the task of putting shape and meaning to these general policies. The European Community has, as a basic aim, the intention of cutting its dependence on oil imports from the present $60 \%$ of energy requirements to around $50 \%$ and possibly $40 \%$ by 1985. Here the North Sea must make a timely and important contribution (which was why Britain was seeking its separate seat at the energy talks in the first place). By 1980 Britain should be producing between 100 million and 130 millions tonnes of oil a year, making it the only country in the EEC self- sufficient in energy. By 1985 Britain's North Sea oil could account for around $45 \%$ of the Community's total energy output; put another way North Sea oil and gas could, by 1985 , be satisfying up to 12 to $15 \%$ of the Community's energy needs. In addition, the North Sea could be providing a privileged source of imports from the Norwegian sector worth perhaps a further $5-7 \%$ of needs.

This is where the importance of a minimum safeguard price comes in. By 1980 some $£ 5,000$ million is likely to have been spent on oil exploration and development in the UK sector of the North Sea. This money (plus a great deal more on ancillary facilities) is being invested on the assumption that oil prices will remain high and provide a reasonable return. If for some political reason Middle East producers decided to slash the price of their oil--and their production costs are a fraction of those in the hostile North Sea-then Britain and the exploration companies will find themselves in deep trouble. As it stands, the 18 members of the IEA have agreed in principle to a floor price of $\$ 7$ a barrel, more than $\$ 4$ below the present market price but sufficient, in the Agency's eyes, to protect the development of alternative sources of energy.

And this is what it is all aboutreducing the industrialised world's dependence on OPEC oil and encouraging the development of other energy providers. Here, the North Sea provides a useful stop-gap, but it would be foolhardy at this stage to overemphasise its long term importance. Even on British Department of Energy estimates, reserves from proven fields are likely to last for only 10 to 20 years, though, of course, new fields are being discovered at an encouraging rate.

Professor Peter Odell, Director of the Economic Geography Institute at Erasmus University, Rotterdam, and an often-quoted authority on energy matters, feels that present and future trends in the North Sea offer "the possibility of a long term supply of indigenous oil capable of bringing the dependence of western Europe on foreign oil down to almost a derisory level."

Undoubtedly new commercial fields will emerge in the North Sea over the 
next decade (a new licensing round in the British sector is planned for later this year). How commercial they prove to be will depend on their size, the ease of recovery and the closeness to existing fields (which should help transporting costs), as well as us the price of oil. Already there is a feeling in the oil industry that the plums of the North Sea have been picked.

In the short to medium term, oil and natural gas must inevitably play a dominant role in the EEC's energy use --around $64 \%$ of total use if the Community's plans come to fruition, a large proportion of these hydrocarbons coming from the North Sea. The importance of natural gas should not be underestimated-the EEC hopes to obtain at least 175 million tonnes of oil equivalent from member countries by 1985; if possible some 225 million tonnes. But what happens when these valuable resources start to dry up? It would be fanciful to predict that some of the more colourful ideas will fill the gap. True a lot of research is going into harnessing energy from waves, tides, the wind and the Sun. On paper many of these possibilities look attractive. For instance, the energy theoretically available from waves is immense -the equivalent to about $70 \mathrm{~kW}$ per metre on the Atlantic-facing coastline of Britain alone. The sheer cost and technical problems put such schemes well into the future, however.

Even if one adds in geothermal heat, which has received so much publicity recently, it is unlikely that these newer methods of raising energy will provide more than $6-8 \%$ of requirements by the end of the century-at least this is the conclusion of a Department of

\section{Turkish poppy industry Straw cogs}

The results of Turkey lifting its ban on the cultivation of opium poppies may surprise the sceptics, argues Peter Collins

THE Turkish Government seems to have scored a major success with its programme to control opium poppy cultivation and hence the illicit production of opium for the world's black market in drugs. Reporting on a visit to the poppy-growing areas at the harvest season, a United Nations official responsible for advising the Turkish government said that "no evidence could be found of opium production in Turkey in 1975". This should reassure those who may have had doubts about the Turks' ability to carry out their intentions, and confound certain United States senators and others who in 1974
Energy 'think tank' (Energy Technology Support Unit) set up in June 1974.

This, then, leaves nuclear power and the 'old faithful', coal, to fill any gap left by a fall-off in oil or gas; or at least to take up much of the energy growth over the next 25 years or so. In some ways this is a daunting prospect, for in Britain this implies an expansion by 20 times of the country's present nuclear capacity by the year 2000; daunting because it poses the problems of technology (which type of reactor should be used), lack of indigenous uranium resources, and public attitudes (the row in the UK over nuclear waste disposal cannot be ignored).

Looking further afield, on present projections nuclear power would need to provide the EEC with $16 \%$ of its energy requirements if the Community is to reach $60 \%$ self-sufficiency by 1985. This is a big leap from the $1.4 \%$ share provided in 1973. The more optimistic projections for the use of nuclear fuel put the amount of installed EEC capacity at 200,000 to 225,000 MW (electrical) by 1985 whereas even the ambitious national plans of member countries go no further than $160,000 \mathrm{MW}$.

All these problems highlight the folly of writing off the coal industry as outdated and unloved. The coal industries in both the UK and Germany are likely to be given a boost over the next few years. Britain, for instance, has just begun to plan for an expansion programme that could take its output back up to 200 million tonnes a year by the end of the century. (In the past decade output has fallen from that

foresaw America being flooded with heroin (the most dangerous opium derivative) when the Turks lifted their complete ban on opium poppy cultivation - a ban imposed largely because of pressure from the United States.

An important factor has always been that the Turkish farmers in the areas concerned have never grown poppies primarily as a source of opium, but rather for the seed and the oil derived therefrom which has traditionally been used as a normal part of their way of life. The Turkish government has prevented disruption of the local farming system by allowing the farmers to grow the poppies, though only on registered, and limited, areas. At the same time it has forbidden the lancing of the fruiting capsules, which must be done to get the opium. By harvesting the poppy straw (as the rest of the plant is called) as a monopoly, the government has also been able to continue supplying the world's pharmaceutical trade with the

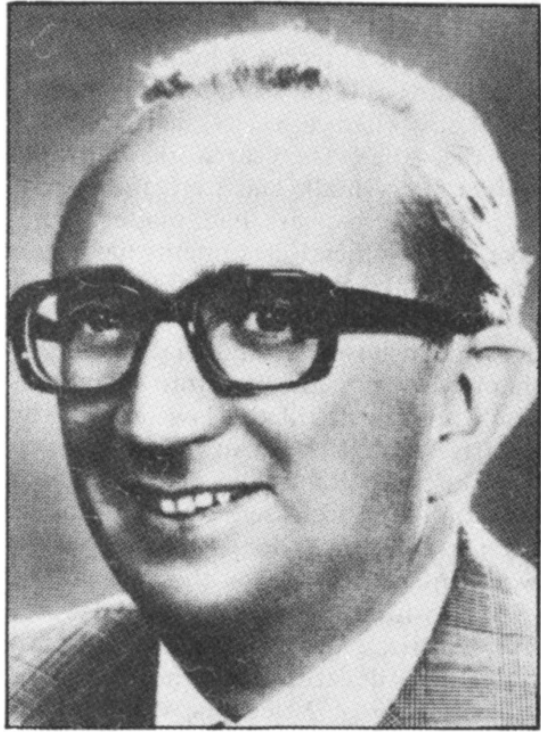

Europe's Energy Commissioner Henri Simonet

level to around 130 million tonnes a year.)

World resources of all types of coal have been estimated to be about 11 million million tonnes of which 700,000 million tonnes are known to be economically recoverable. But, coal or geothermal power, it is too early to assess with accuracy the relative importance of different forms of power even over the next decade. Policies are still emerging. But at least the industrialised world has learned the hard way that it must make the most of all available resources. It must be efficient in its use of energy, but above all it must be flexible.

raw material from which codeine, and hence various other materials, are extracted. All this has helped avoid a world shortage of codeine as well as cut off a potential source of illicit heroin.

No one expects a major programme like this to be a total success immediately. At least one of the problems raised could hardly have been foreseen. During an inspection tour of the growing areas, the UN team found that the government measures were if anything being too harshly applied. The areas that farmers had been allowed to sow were laid down in hectares, and a considerable number of farmers were found to have sown more than the area for which their licences allowed. The local farmers, it seems, think in terms of the dunum, an area which is actually slightly larger than the decare $(1 / 10$ th of a hectare). Although this was a genuine mistake. understandable in a country where almost every region has 